\title{
Activity of Fungicides Against Monilinia vaccinii-corymbosi in Blueberry Flowers Treated at Different Phenological Stages
}

\author{
T. L. B. Tarnowski, A. T. Savelle, and H. Scherm, Department of Plant Pathology, University of Georgia, Athens \\ 30602
}

\begin{abstract}
Tarnowski, T. L. B., Savelle, A. T., and Scherm, H. 2008. Activity of fungicides against Monilinia vaccinii-corymbosi in blueberry flowers treated at different phenological stages. Plant Dis. 92:961-965.

The activity of fenbuconazole and azoxystrobin applied to blueberry flowers at different phenological stages against subsequent gynoecial infection by the mummy berry fungus Monilinia vaccinii-corymbosi was evaluated. In the greenhouse, potted blueberry plants having flower clusters at five distinct stages (from bud scale separation to anthesis) were treated with the two fungicides. One day after anthesis (between 1 and 15 days after fungicide treatment), individual flowers were detached and inoculated with conidia of $M$. vaccinii-corymbosi in the laboratory. Four days after inoculation, hyphal ingress into the style was determined microscopically as a measure of fungicide efficacy. Results revealed a significant flower stage effect $(P<0.0001)$, whereby only fungicide application at anthesis but not at the four preanthesis stages reduced subsequent fungal ingress into the style. There was no significant difference between the two fungicides $(P>0.50)$ nor was there a significant fungicide-flower stage interaction $(P>0.30)$. In the field during 2 years, mature blueberry plants were treated with the two fungicides and exposed to natural pathogen inoculum. At the time of application, flower clusters at anthesis and at three preanthesis stages were selected and tagged. Mummy berry incidence in fruit developing from the tagged clusters was assessed to determine treatment effects. Whereas fenbuconazole lowered disease incidence for all preanthesis stages, azoxystrobin was effective only at the latest preanthesis stage. The discrepancy between these results and those of the greenhouse study (where there was no preanthesis activity of either fungicide) indirectly suggests post-infection fungicidal activity in the ovary, the base of which was exposed to the fungicide spray at the time of treatment for all flower phenology stages. Thus, although there appears to be insufficient translocation of the two fungicides in flowers treated at preanthesis stages to prevent stylar ingress by the pathogen, fungicidal activity in the ovary may be sufficient to halt subsequent fungal colonization, especially for fenbuconazole. To prescribe the most effective management program for flower-infecting fungi, translocation and post-infection activity of fungicides in floral tissues must be better understood.
\end{abstract}

Additional keywords: demethylation inhibitor, quinone outside inhibitor, rabbiteye blueberry, Vaccinium virgatum

During the past 25 years, blueberry (Vaccinium section Cyanococcus) has emerged as an important crop in Georgia, surpassing peach as the fruit crop with the highest utilized value of production in 2005 and 2006 (1). In part due to the recent recognition of the health benefits associated with blueberry fruit consumption $(12,29)$, the production area of blueberry statewide has risen from $<500$ ha in the 1980 s to $>3,600$ ha in $2005(4,20)$.

Mummy berry disease, caused by the fungus Monilinia vaccinii-corymbosi, is a major disease confronting blueberry growers in North America $(3,7,10)$. In a survey

Corresponding author: H. Scherm

E-mail: scherm@uga.edu

Accepted for publication 13 February 2008.

doi:10.1094/PDIS-92-6-0961

(C) 2008 The American Phytopathological Society published in $2001,>75 \%$ of Georgia blueberry producers reported mummy berry as a major or moderate disease problem (21). Most losses associated with the disease are due to the rejection or downgrading of commercial blueberry shipments that contain mummified fruit (19).

Fruit mummification by $M$. vacciniicorymbosi is the result of conidial infection of open flowers through the stigma and style, whereby fungal hyphae grow through the gynoecial pathway into the ovary to colonize the developing fruit internally $(14,23)$. As the fruit develop, the locules of the ovaries are filled with dense mycelial growth. The hyphae migrate into the mesocarp, in which a pseudosclerotium (mummy) forms during the fruit maturation process. Mummified fruit fall to the ground where they oversummer and overwinter, serving as the source of primary inoculum in the following spring $(3,13)$. Ascospores, produced in apothecia formed on overwintered mummies, incite primary infection in late winter or early spring, blighting emerging leaves and shoots (primary infection). Conidia produced on blighted tissue subsequently serve as the source of inoculum for infection of open flowers during bloom (secondary infection).

Management of mummy berry disease requires repeated applications of fungicide from vegetative bud break through the end of bloom in order to mitigate both shoot blight and flower infection. To minimize the number of sprays needed for disease control, host phenology-based application schedules have been developed $(6,22,25-$ 27). Since the 1990s, the demethylation inhibitor (DMI) fenbuconazole (Indar) has become the standard for managing primary and secondary infection by $M$. vacciniicorymbosi $(22,25-27)$. In Georgia, two to three bloom applications of fenbuconazole proved effective in controlling mummy berry disease (22). Other active ingredients currently labeled against the disease include the quinone outside inhibitors (QoIs) azoxystrobin (Abound) and pyraclostrobin + boscalid (Pristine).

An important problem with timing bloom sprays against mummy berry disease is the high degree of variability in bloom progression among blueberry cultivars and years. During favorable weather, numerous new infection courts (stigmatic surfaces) can become exposed to inoculum within a few days. Conversely, less favorable environmental conditions can lead to a highly protracted bloom period. It is unknown to what degree the pistils of flowers treated before anthesis (when the pistil is still enclosed by the corolla) are protected from infection after the flowers open. Any preanthesis activity of fungicides in flowers should be related to (i) the ability of the applied active ingredient to translocate into the style from the base of the ovary, the only part of the pistil exposed during spray application to unopened flowers; and (ii) the post-infection activity of the fungicide in the ovary, where it may prevent colonization after successful pathogen ingress through stigma and style. In general, DMIs have more pronounced systemic properties $(8,28)$ and post-infection activity $(5,9,17)$ than QoI fungicides, whose translocation often is limited to translaminar movement (2). However, there is no specific information on mobility and activity of different fungicidal compounds in flowers. In the 
field, fenbuconazole is consistently effective in controlling secondary infection by M. vaccinii-corymbosi, whereas azoxystrobin generally exhibits lower or more variable levels of control for the same number of applications $(22,25,27)$. This difference in efficacy may be due, in part, to different degrees of mobility of the two compounds in the floral tissues through which the pathogen infects.

This study sought to determine the duration of control afforded by fenbuconazole and azoxystrobin against $M$. vaccinii- corymbosi in blueberry flowers treated at different phenological stages. Experiments were carried out (i) in controlled conditions by assessing hyphal ingress of $M$. vacciniicorymbosi into the styles of artificially inoculated flowers taken from greenhousegrown plants previously treated with the two fungicides and (ii) in the field in the presence of natural inoculum by comparing the incidence of fruit infection in plants treated with the fungicides when a range of distinct flower phenology stages was present.
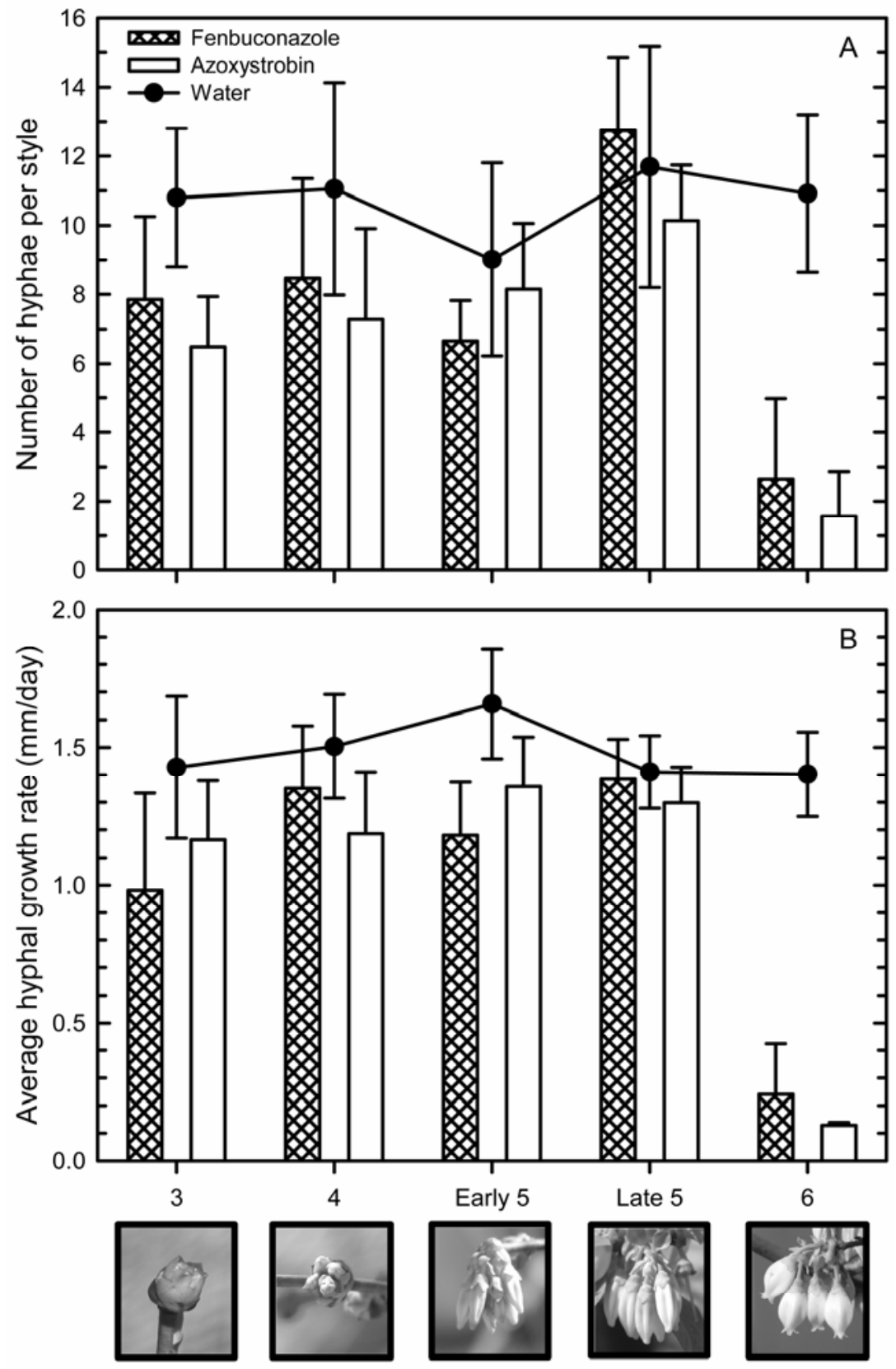

Flower stage at fungicide application

Fig. 1. Hyphal ingress of Monilinia vaccinii-corymbosi into flower styles of greenhouse-grown Climax rabbiteye blueberry in relation to fungicide active ingredient and flower stage at the time of fungicide application. A, Number of hyphae that penetrated at least $20 \%$ of the length of the style. B, Average hyphal growth rate per style. Flowers were treated with fungicide at the stages indicated, detached, inoculated with conidia of $M$. vaccinii-corymbosi 1 day after anthesis, and fixed for microscopic assessment 4 days later. Values are means and standard errors of five replicate experiments, each with eight styles per treatment combination.

\section{MATERIALS AND METHODS}

Greenhouse experiments. Four- to five-year-old rabbiteye blueberry plants (Vaccinium virgatum cv. Climax) were maintained in 11.4-liter pots in a cold room $\left(5\right.$ to $\left.6^{\circ} \mathrm{C}\right)$ during the winter. At intervals from early January to early May, groups of plants were moved to a greenhouse maintained at 24 to $28^{\circ} \mathrm{C}$ to obtain subsets of plants with staggered bloom periods. Each individual run of the experiment was carried out when a sufficient number of flower clusters at the designated phenological stages (see below) was available. The experiment was carried out five times over two growing seasons, and the individual experimental runs were considered replicates (blocks) in the analysis.

The experimental design was a split-plot with fungicide (three levels) as the main plot and flower phenology stage (five levels) as the subplot. Each main plot consisted of a single plant having all five flower stages present simultaneously. $\mathrm{Nu}-$ merical flower stages (24) at the time of fungicide treatment were $3=$ bud scales separated, apices of flowers visible; $4=$ individual flowers distinguishable, bud scales abscised; early $5=$ individual flowers distinctly separated and corollas short, unexpanded, and closed; late $5=$ individual flowers distinctly separated and corollas longer and somewhat expanded, but still closed; and early $6=$ anthesis (i.e., corollas completely expanded, flowers open). On the day of fungicide treatment, six flower clusters per stage were tagged on each plant using colored embroidery thread.

Fungicide treatments consisted of a single application of fenbuconazole (Indar 75WSP; $0.3 \mathrm{~g}$ of formulated product per liter; Dow AgroSciences, Indianapolis, $\mathrm{IN}$ ), azoxystrobin (Abound SC; $1.9 \mathrm{ml}$ formulated product per liter; Syngenta Crop Protection, Greensboro, NC), or a water control. Each plant was treated with 0.3 liters of fungicide suspension or water using a 7.6-liter handheld sprayer.

Individual flowers at stage 6 (newly open at the time of fungicide application) were detached 1 day after treatment, positioned in microtiter plate wells in the laboratory, and inoculated with conidia of $M$. vaccinii-corymbosi as described by Ngugi et al. (16), except that oat bran agar was used for fungal culture instead of oatmeal agar. Oat bran agar was prepared by boiling $20 \mathrm{~g}$ of oat bran in $600 \mathrm{ml}$ of deionized water, simmering for $40 \mathrm{~min}$ with frequent stirring, filtering the suspension through cheesecloth, and bringing the total volume to $750 \mathrm{ml}$ with deionized water prior to adding $10 \mathrm{~g}$ of agar and autoclaving. Detached flowers were used for inoculation because they allowed for precise application of conidia under a stereomicroscope. Previous work in our laboratory documented a highly significant linear correlation between hyphal growth rates in de- 
tivity provided by fungicides is important in determining the application timing and frequency necessary to protect against infection by this pathogen. In recent field studies, fungicides have been applied according to bloom phenology rather than based on calendar days, resulting in considerably shorter application intervals than specified by the product labels in years when bloom progressed rapidly $(25,26)$. Timing and frequency of applications could be improved if the preinfection ac- tivity of fungicides applied prior to anthesis could be quantified. This was intended in the present study.

The greenhouse study showed that, for both fenbuconazole and azoxystrobin, only flowers treated at anthesis (stigmas exposed to direct fungicide coverage) were protected from stylar penetration by $M$. vaccinii-corymbosi following artificial inoculation. Flowers sprayed prior to anthesis showed no decrease in hyphal penetration when they were inoculated after

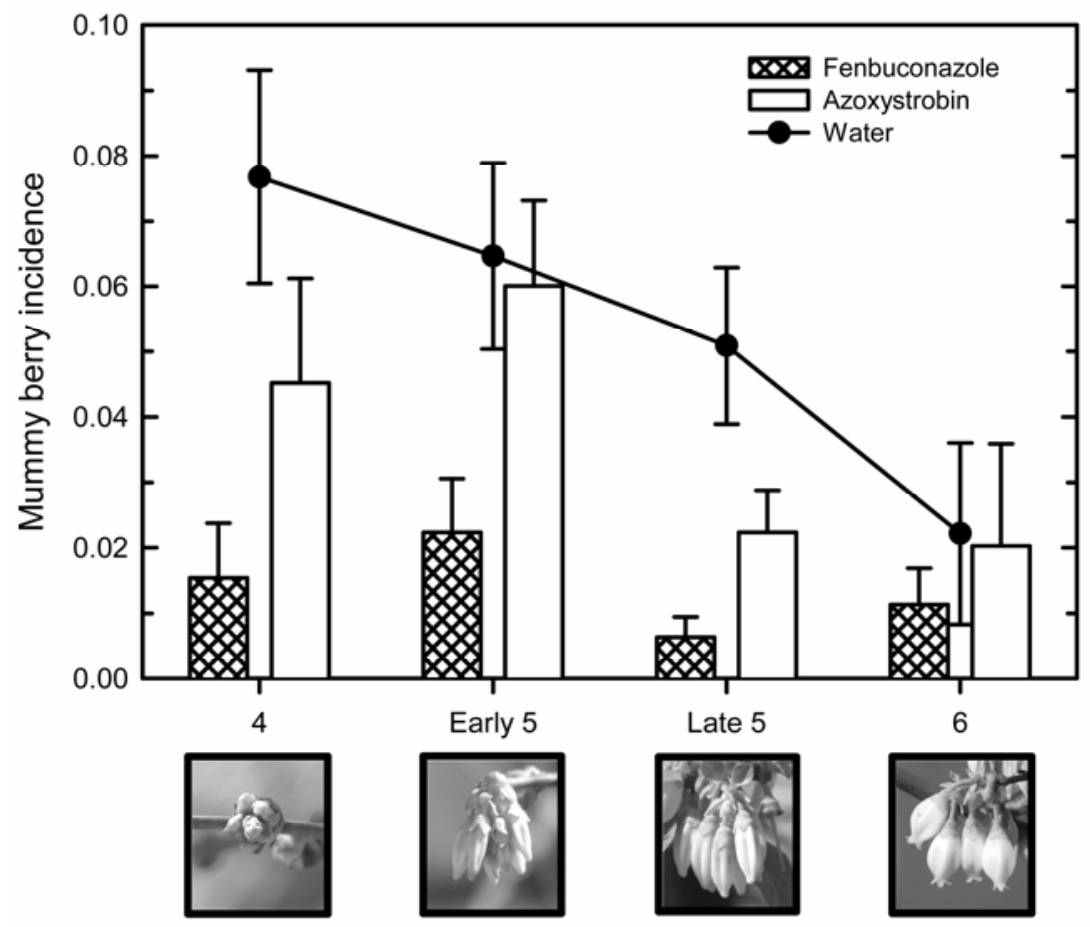

Flower stage at fungicide application

Fig. 2. Incidence of fruit infection by Monilinia vaccinii-corymbosi on Tifblue rabbiteye blueberry in the field in relation to fungicide active ingredient and flower stage at the time of fungicide application. Flower clusters were treated with fungicide at the stages indicated, exposed to natural inoculum of $M$. vaccinii-corymbosi, and fruit developing from these clusters were harvested and assessed for disease incidence. Values are means and standard errors of eight replications (four replicate plots in each of 2 years), each with 12 flower clusters per treatment combination.

Table 2. Results of a split-plot analysis of variance to determine the effects of fungicide, flower stage at the time of fungicide application, and their interaction on the incidence of fruit infection by Monilinia vaccinii-corymbosi on Tifblue rabbiteye blueberry in the field ${ }^{\mathrm{a}}$

\begin{tabular}{lcccc}
\hline Source & df & Mean square & $\boldsymbol{F}$ & $\boldsymbol{P}>\boldsymbol{F}$ \\
\hline Replication $^{\mathrm{b}}$ & 7 & $3,484.5$ & 2.86 & 0.0943 \\
Fungicide (main plot) $^{\mathrm{c}}$ & 1 & $7,351.9$ & 6.04 & 0.0436 \\
Main plot error $^{\text {Flower stage (subplot) }}{ }^{\mathrm{d}}$ & 7 & $1,217.1$ & $\ldots$ & $\ldots$ \\
Fungicide-flower stage interaction $_{\text {Subplot error }}$ & 3 & $2,531.1$ & 2.22 & 0.0995 \\
& 3 & $2,155.8$ & 1.89 & 0.1453 \\
\hline
\end{tabular}

a Flower clusters were treated with fungicide at the stages indicated below and exposed to natural inoculum of $M$. vaccinii-corymbosi; fruit developing from these clusters were harvested and assessed for disease incidence. Analysis based on values expressed as a percentage of the water control.

${ }^{\mathrm{b}}$ Combined data from 2 years with four replications per year.

${ }^{\mathrm{c}}$ Indar 75WSP (fenbuconazole) or Abound (azoxystrobin) applied as formulated products at $0.3 \mathrm{~g} / \mathrm{liter}$ and $1.9 \mathrm{ml} /$ liter, respectively.

${ }^{\mathrm{d}}$ Numerical flower stages (24) at the time of fungicide treatment were $4=$ individual flowers distinguishable, bud scales abscised; early 5 = individual flowers distinctly separated and corollas short, unexpanded, and closed; late $5=$ individual flowers distinctly separated and corollas longer and somewhat expanded, but still closed; and early $6=$ anthesis (i.e., corollas completely expanded, flowers open).

they opened 1 to 15 days after application, suggesting that neither fungicide was translocated from the ovary, the only exposed part of the pistil in preanthesis flowers, into the style or stigma in sufficient concentration to prevent hyphal ingress by the pathogen. A similar conclusion, albeit for a different pathosystem, was reached by Ryley et al. (18), who found that, in their spray timing trials against Claviceps africana, another fungus that infects through the stigma and style, systemic protection of sorghum panicles by DMI fungicides was limited. Although DMIs generally are more systemic than QoI fungicides, fenbuconazole appears to have translaminar rather than fully systemic activity (28). The lack of conidial germination in stage- 6 flowers treated with azoxystrobin is consistent with the compound's activity as a spore germination inhibitor, whereas fenbuconazole, a triazole fungicide, does not inhibit spore germination and early germ tube growth $(2,28)$.

In the field study, fenbuconazole showed considerable activity against infection by M. vaccinii-corymbosi when applied preanthesis, whereas there was no such activity in the greenhouse study. The discrepancy between the two studies indirectly suggests post-infection fungicidal activity of fenbuconazole in the ovary, the base of which is the only part of the pistil directly covered by fungicide in flowers sprayed before anthesis. Although fenbuconazole does not appear to move systemically from the ovary into the style (as indicated by the greenhouse study), it may translocate within the ovary and halt colonization by the pathogen after the hyphae have entered through the style. In leaf tissue, DMI fungicides show some post-infection activity when applied shortly after infection $(5,9,17,28)$; such activity also could be present in flowers and could explain why some control has been noted in the field even when sprays are applied at early flower phenology stages or at longer intervals $(6,25)$. Future studies which measure both hyphal ingress and ovary colonization are needed to clarify this aspect of the activity of fenbuconazole.

The preanthesis activity of azoxystrobin in the field was considerably weaker than that of fenbuconazole, being limited to late stage-5 flowers. This is consistent with previous reports $(22,25)$ that azoxystrobin generally is less effective in managing the secondary infection phase of mummy berry disease. The compound acts mostly by inhibiting spore germination (2), requiring application before germination of conidia to be most effective. The lower efficacy of azoxystrobin in the field also could have been due to the fact that flower phenology could not be controlled as precisely in the field as in the greenhouse study. Previous laboratory work (16) showed a significant effect of flower age (time after anthesis) on infection success 
by $M$. vaccinii-corymbosi, whereby newly opened flowers were most receptive to infection and receptivity decreased rapidly with increasing flower age. In the present study, stage- 6 flowers in the greenhouse were sprayed the day they opened and inoculated 1 day later, an age at which fungal ingress would have been expected to be near optimum. In contrast, in the field, it was not possible to determine how long stage- 6 flowers had been open before fungicide application or how soon before or after application they were exposed to conidia of $M$. vaccinii-corymbosi. Thus, the flowers may have been infected already at the time of treatment, or they may have been infected after the azoxystrobin treatment was most effective.

In a broader context, this study highlights the need to determine mobility and activity of fungicidal active ingredients in floral tissues, because flowers are physiologically very different from leaves. Knowledge of a compound's activity in leaves cannot be extrapolated to flowers; hence, for the numerous pathosystems involving flowers (15), it is more difficult to prescribe chemical control measures. Further research investigating translocation and post-infection activity of different active ingredients against $M$. vacciniicorymbosi would be useful, including documentation of the inhibition of mycelial colonization via residual activity in the ovary after successful penetration of the style has occurred.

\section{ACKNOWLEDGMENTS}

We thank H. Ngugi, P. Brannen, and D. Stanaland for useful discussions; and B. Kitchen for allowing us to conduct research on his blueberry farm.

\section{LITERATURE CITED}

1. Anonymous. 2007. Noncitrus Fruits and Nuts, 2006 Preliminary Summary. USDA-NASS, Washington, DC.

2. Bartlett, D. W., Clough, J. M., Godwin, J. R., Hall, A. A., Hamer, M., and Parr-Dobrzanski,
B. 2002. The strobilurin fungicides. Pest Manage. Sci. 58:649-662.

3. Batra, L. R. 1983. Monilinia vacciniicorymbosi (Sclerotiniaceae): its biology on blueberry and comparison with related species. Mycologia 75:131-152.

4. Boatright, S. R., and McKissick, J. C. 2006. 2005 Georgia Farm Gate Value Report, AR 0601. University of Georgia Center for Agribusiness and Economic Development, Athens.

5. Bushong, P. M., and Timmer, L. W. 2000. Evaluation of postinfection control of citrus scab and melanose with benomyl, fenbuconazole, and azoxystrobin. Plant Dis. 84:12461249.

6. Copes, W. E., and Stanaland, R. D. 1999. Evaluation of fungicide timing for control of blueberry mummy berry, 1998. Fungic. Nematicide Tests 54:89.

7. Eck, P. 1988. Blueberry Science. Rutgers University Press, New Brunswick, NJ.

8. Garland, S. M., Menary, R. C., and Davies, N. W. 1999. Dissipation of propiconazole and tebuconazole in peppermint crops (Mentha peperita (Labiatae)) and their residues in distilled oils. J. Agric. Food Chem. 47:294-298.

9. Hoffman, L. E., and Wilcox, W. F. 2003. Factors influencing the efficacy of myclobutanil and azoxystrobin for control of grape black rot. Plant Dis. 87:273-281.

10. Honey, E. E. 1936. North American species of Monilinia. I. Occurrence, grouping, and lifehistories. Am. J. Bot. 23:100-106.

11. Littell, R. C., Freund, R. J., and Specter, P. C. 1991. SAS System for Linear Models, 3rd ed. SAS Institute, Cary, NC.

12. McCord, H. 1999. The miracle berry. Prevention 51(6): 122-127.

13. Milholland, R. D. 1977. Sclerotium germination and histopathology of Monilinia vacciniicorymbosi on highbush blueberry. Phytopathology 67:848-854.

14. Ngugi, H. K., and Scherm, H. 2004. Pollen mimicry during infection of blueberry flowers by conidia of Monilinia vaccinii-corymbosi. Physiol. Mol. Plant Pathol. 64:113-124.

15. Ngugi, H. K., and Scherm, H. 2006. Biology of flower-infecting fungi. Annu. Rev. Phytopathol. 44:261-282.

16. Ngugi, H. K, Scherm, H., and Lehman, J. S. 2002. Relationships between blueberry flower age, pollination, and conidial infection by Monilinia vaccinii-corymbosi. Phytopathology 92:1104-1109.

17. O'Leary, A. L., and Sutton, T. B. 1986. Effects of postinfection applications of ergo- sterol biosynthesis-inhibiting fungicides on lesion formation and pseudothecial development of Venturia inaequalis. Phytopathology 76:119-124.

18. Ryley, M., Bhuiyan, S., Herde, D., and Gordan, B. 2003. Efficacy, timing and method of application of fungicides for management of sorghum ergot caused by Claviceps africana. Australas. Plant Pathol. 32:329-338.

19. Scherm, H., and Copes, W. E. 1999. Evaluation of methods to detect fruit infected by Monilinia vaccinii-corymbosi in mechanically harvested rabbiteye blueberry. Plant Dis. 83:799-805.

20. Scherm, H., and Krewer, G. 2003. Blueberry production in Georgia: historical overview and recent trends. Small Fruits Rev. 2(4):83-91.

21. Scherm, H., NeSmith, D. S., Horton, D. L., and Krewer, G. 2001. A survey of horticultural and pest management practices of the Georgia blueberry industry. Small Fruits Rev. 1(4):1728.

22. Scherm, H, and Stanaland, R. D. 2001. Evaluation of fungicide timing strategies for control of mummy berry disease of rabbiteye blueberry in Georgia. Small Fruits Rev. 1(3):69-81.

23. Shinners, T. C., and Olson, A. R. 1996. The gynoecial infection pathway of Monilinia vaccinii-corymbosi in lowbush blueberry (Vaccinium angustifolium). Can. J. Plant Sci. 76:493497.

24. Spiers, J. M. 1978. Effect of stage of bud development on cold injury in rabbiteye blueberry. J. Am. Soc. Hortic. Sci. 103:452-455.

25. Stanaland, R. D., Brannen, P. M., and Scherm, H. 2004. Fungicidal control of mummy berry disease of blueberry, 2003. Fungic. Nematicide Tests 59:SMF022.

26. Stanaland, R. D., Brannen, P. M., and Scherm, H. 2005. Fungicidal control of mummy berry disease of blueberry, 2004. Fungic. Nematicide Tests 60:SMF031.

27. Stanaland, R. D., Scherm, H., and Savelle, A. T. 2000. Evaluation of fungicides and application timings for mummy berry disease contro in blueberry, 1999. Fungic. Nematicide Tests 55:89.

28. Tsuda, M., Itoh, H., and Kato, S. 2004. Evaluation of the systemic activity of simeconazole in comparison with that of other DMI fungicides. Pest Manage. Sci. 60:875-880.

29. Zheng, W., and Wang, S. Y. 2003. Oxygen radical absorbing capacity of phenolics in blueberries, cranberries, chokeberries, and lingonberries. J. Agric. Food Chem. 51:502-509. 